\title{
MITEN AUTISMIKIRJON HENKILÖT JA VERROKIT KUVAILEVAT JA ESITTÄVÄT TOISEN HENKILÖN AJATUKSIA?
}

Maria Frick, Kielten ja kirjallisuuden tutkimusyksikkö, Oulun yliopisto

Soile Loukusa, Logopedian tutkimusyksikkö, Oulun yliopisto Katja Dindar, Logopedian tutkimusyksikkö, Oulun yliopisto Leena Mäkinen, Logopedian tutkimusyksikkö, Oulun yliopisto

Marja-Leena Mattila, PEDEGO-tutkimusyksikkö, Lääketieteellinen tiedekunta, Oulun yliopisto ja Lastenpsykiatrian vastuualue, Oulun yliopistollinen sairaala

Hanna Ebeling, PEDEGO-tutkimusyksikkö, Lääketieteellinen tiedekunta, Oulun yliopisto ja Lastenpsykiatrian vastuualue, Oulun yliopistollinen sairaala

Tuula Hurtig, Neurotieteen tutkimusyksikkö, PEDEGOtutkimusyksikkö, Oulun yliopisto ja Lastenpsykiatrian vastuualue, Oulun yliopistollinen sairaala

\footnotetext{
Tarkastelemme referointikeinoja, joita aikuiset autismikirjon henkilöt ja verrokit käyttävät puhuessaan toisen henkilön ajatuksista. Aineisto on kerätty tutkimustilanteessa, jossa tutkittavia pyydetään kertomaan, mitä videolla nähty henkilö voisi ajatella. Tässä tutkimuksessa referointikeinot on luokiteltu kuvaileviksi ja esittäviksi sen mukaan, pysyykö vuoron näkökulma eli deonttinen origo meneillään olevassa puhetilanteessa vai siirtyykö se referoitavaan puhetilanteeseen. Tutkimus osoittaa, että autismikirjon henkilöiden ja verrokkien referointikeinot ovat pääosin samankaltaisia, joskin verrokkiryhmän edustajien vastauksissa on hieman enemmän
}

Kirjoittajan yhteystiedot:

Maria Frick

maria.frick@oulu.fi 
kuvailua ja autismikirjon henkilöillä esitystä. Kaksi tutkittavaa autismikirjon henkilöä käyttää myös ns. paljaita esityksiä, jotka eivät sisällä lainkaan sellaisia deonttisia markkereita, jotka sitoisivat sanotun meneillä olevaan puhetilanteeseen. Tällainen referointi on suomenkielisessä puheessa melko harvinaista, ja katsomme sen mahdollisesti kuvastavan yksittäisten autismikirjon henkilöiden erilaista tapaa hahmottaa tai käsitellä puhetilanteen osallistumiskehikkoa.

Avainsanat: autismikirjo, intersubjektiivisuus, referointi, suora esitys

\section{JOHDANTO}

Tämän artikkelin tarkastelukohteena on se, miten haastattelua muistuttavassa tutkimustilanteessa referoidaan toisen henkilön ajatuksia. Tutkimuksen tavoitteena on lisätä tietoa esittämisestä puhetoimintona ja suomen kielen tarjoamista keinoista ilmaista referointia. Tutkimus pyrkii myös selvittämään, onko joillakin tutkimukseen osallistuvista autismikirjon henkilöistä tai heidän verrokeistaan käytössään harvinaisempia referointikeinoja.

Tutkimustilanteessa osallistujille näytetään video ja heiltä kysytään, mitä videolla nähty henkilö mahtaa ajatella. Aineistomme koostuu näistä vastauksista. Tutkimuksemme on aineistovetoinen, ja hyödynnämme siinä kielitieteellistä ja keskustelunanalyysiin pohjautuvaa käsitteistöä.

Autismikirjon häiriö on neurobiologinen kehityshäiriö, jonka oirekuvaan kuuluvat sosiaalisen vuorovaikutuksen ja kommunikaation vaikeudet sekä rajoittunut, toistava ja kaavamainen käyttäytyminen (ICD-11, World Health Organization, 2018). Nämä oireet vaikuttavat siihen, miten henkilö ilmaisee itseään ja ymmärtää muita, miten hän on vuorovaikutuksessa muiden kanssa sekä miten hän kokee ympäröivän maailman. Autismikirjon häiriöön liittyy usein myös monenlaisia neurokognitiivisia puutteita (esim. tarkkaavuus ja muisti) ja aistipoikkeavuuksia (ks. esim. Moilanen, Mattila, Loukusa \& Kielinen, 2012), jotka ovat myös osaltaan vaikuttamassa henkilön tapaan kommunikoida muiden ihmisten kanssa.

Yksi autismikirjon häiriöön usein liitetyistä ominaisuuksista on tavanomaisesta poikkeava tapa hahmottaa toisen henkilön ajatuksia (Baron-Cohen, 2001, 2009). Emme tässä tutkimuksessamme suoranaisesti pyri kuvaamaan ihmisten ajattelua. Sen sijaan esitämme empiirisiä havaintoja eri tavoista kielentää toisen henkilön ajatuksia. Kielellisellä ilmaisulla siinä missä muullakin sosiaalisella toiminnalla on toki kognitiivinen ja neurologinen perusta, ja nähdäksemme tässä esitetyt havainnot heijastavat sitä, miten puhujat käsittelevät puhetilanteen osallistumiskehikkoa eli läsnäolijoita, heidän välisiään suhteita ja tilanteessa jaettua tietoa. Kuviossa 1 on kuvattu tutkimiemme referointitilanteiden osallistumiskehikko. 


\section{referoitava}

\section{puhuja}
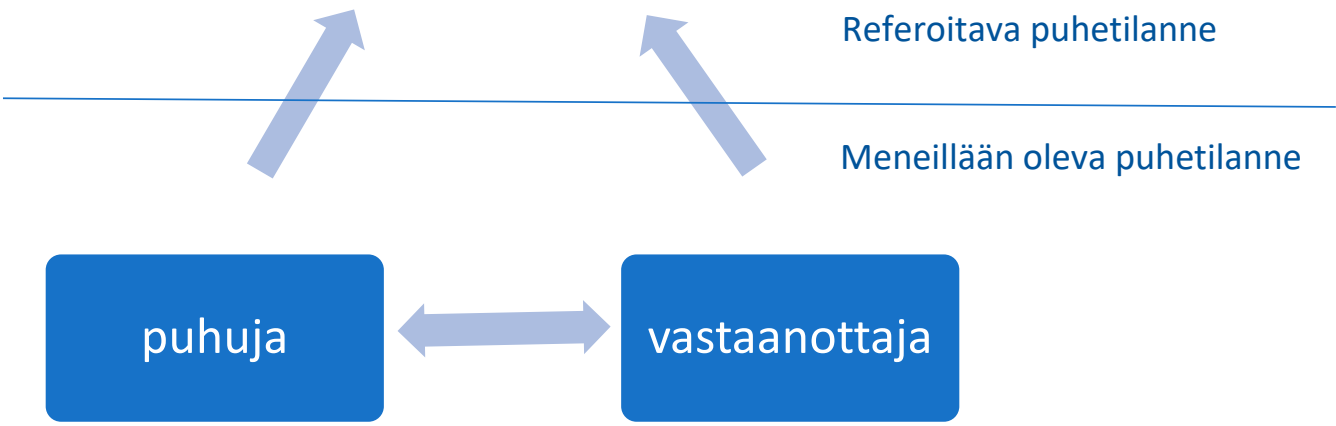

KUVIO 1. Referointitilanteen osallistumiskehikko

Kuviossa 1 kuvataan referointitilanteen osallistumiskehikkoa, jossa on puhujan ja vastaanottajan lisäksi tavallaan läsnä myös kolmas osapuoli ja toinen puhetilanne. Kuvion nuolet kuvastavat intersubjektiivisia linkkejä (ks. esim. Eiguer, 2017) eli sidoksia, jotka yhdistävät puhujan ja vastaanottajan molemminsuuntaiseen jaettuun kokemukseen ja sitovat siihen myös referoitavan tilanteen, vaikka referoitava puhuja ei jaakaan yhteistä kokemusta. Intersubjektiiviset linkit sitovat vuorovaikutuksen osapuolet toisiinsa ja mahdollistavat toisen ymmärtämisen emotionaalisella ja tietotasolla (Eiguer, 2017). Scharffin mukaan intersubjektiivisuus perustuu ihmisten välisessä vuorovaikutuksessa tapahtuvaan jatkuvaan sykliseen toisen henkilön emootioiden tunnistamiseen ja omien tunteiden projisoimiseen (Scharff, 2017, s. 230). Intersubjektiivisuudella ajatellaan olevan neurologinen perusta, ja autismikirjon henkilöillä on havaittu intersubjektiivisuuden ilmaisun poikkeavuutta (Gallese, 2011).

Vaikka suomen kielen referoinnista on jonkin verran tutkimusta, johon voimme verrata aineistoamme, autismikirjon henkilöiden referointikeinoja ei liene aiemmin tutkittu suomenkielisellä aineistolla. Kansainvälisestä tutkimuksesta sen sijaan löytyy viitteitä siitä, että autismikirjon henkilöt saattavat käyttää referointia muista poikkeavalla tavalla (ks. esim. Cummings, 2016; Engberg-Pedersen \& Christensen, 2017). Tutkimuksissa esitetyt esimerkit ovat useimmiten aiemman puheen kierrätystä ja sitaattien käyttöä silloin, kun odotuksenmukaista olisi muotoilla vuoro puhujan omasta näkökulmasta. Aiemmassa tutkimuksessa on yleensä keskitytty autismikirjon lapsiin, ja vähemmän tietoa onkin aikuisten autismikirjon henkilöiden referointikeinoista.

Tämä tutkimus antaa uutta tietoa suomen kielen referoinnin keinoista, kuvailusta ja esittämisestä puhetoimintoina ja siitä, onko autismikirjon diagnoosin saaneiden henkilöiden ja verrokkien tavoissa referoida toisen henkilön ajatuksia mahdollisesti eroavuuksia. Tutkimuskysymyksemme ovat 1) Millaisin kielellisin keinoin esittäviä vuoroja muodostetaan? ja 2) Onko esittävien 
vuorojen rakenteessa erityispiirteitä, joita ei ole havaittu aiemmissa tutkimuksissa? Tutkimuskysymyksiin vastataan luvussa 5, jossa kuvaillaan esittävien vuorojen kielellisiä piirteitä. Luvussa 3 kerrotaan tutkimusaineistosta ja analyysimenetelmistä ja luvussa 4 siitä, miten kuvailevat ja esittävät vuorot jakautuvat aineistossa. Seuraavassa luvussa 2 kerrotaan autismikirjon henkilöiden referointikeinojen tutkimuksen taustaa.

\section{AIEMPAA TUTKIMUSTA AUTISMIKIRJON HENKILÖIDEN REFEROINTIKEINOISTA}

Autismikirjon henkilöiden kielellinen ilmaisu on ollut kiinnostuksen kohteena erityisesti viimeisen kymmenen vuoden aikana (esim. Mäkinen et al., 2014; Sng, Carter \& Stephenson, 2018; Tek, Mesite, Fein \& Naigles, 2014, ks. myös Loukusa, painossa). Oman aiheemme kannalta kiinnostavimpia ovat tutkimukset, jotka liittyvät referointiin ja ylipäätään deiksikseen eli siihen, miten sanottu on sidottu aikapaikkaiseen kontekstiinsa (ks. esim. Bühler, 2011 [1934], s. 93-116; VISK \$1423). Melko lähelle omaa aihettamme osuu Engberg-Pedersenin ja Christensenin (2017) tutkimus alakouluikäisten lasten kertomista tarinoista ja siitä, miten autismikirjon lapset ja verrokit ilmaisivat tarinan hahmojen ajatuksia. Heidän aineistossaan autismikirjon lapsilla on vähemmän toisen henkilön ajattelun kuvailua kuin verrokeilla (Engberg-Pedersen \& Christensen, 2017, s. 1206-1207). Vastaavia tuloksia on saatu myös tutkittaessa aikuisia autismikirjon henkilöitä: Autismikirjon henkilöt tuottavat vähemmän viittauksia videolta nähtyjen hahmojen mielentiloihin kuin verrokit (esim. Barnes, Lombardo, Wheelwright, \& Baron-Cohen, 2009). Toisaalta kaikissa tutkimuksissa eroja ryhmien välillä ei ole löydetty (esim. Freeth, Ropar, Mitchell, Chapman, \& Loher, 2011), mikä voi liittyä esimerkiksi eroihin tutkimuksissa käytetyissä ärsykkeissä tai tapoihin, joilla tutkittavien kerrontaa on analysoitu. Kerronnan sisällön analyysin sijasta (mitä tutkittavat kertovat) onkin mielestämme tärkeää tarkastella myös kerronnan tapaa (miten tutkittavat rakentavat kerrontaansa). Engberg-Pedersen ja Christensen (2017) vertaavatkin suoran ja epäsuoran esityksen määriä ja toteavat autismikirjon lasten käyttävän enemmän suoraa kuin epäsuoraa esitystä.

Jo yli 70 vuotta sitten Kanner kiinnitti raportissaan huomiota erään autismikirjon lapsen tapaan käyttää matkimista (parroting) arkisissa vuorovaikutustilanteissa. Kannerin tutkima poika referoi käyttämällä "siteeraamansa henkilön persoonapronomineja ja matki jopa intonaatiota” silloin, kun odotuksenmukaista olisi ollut puhua omasta näkökulmastaan. Esimerkiksi halutessaan äidin ottavan häneltä kengän jalasta poika sanoi Pull off your shoe ja halutessaan kylpyyn Do you want a bath. (Kanner, 1943, s. 219.) Kannerin kuvaama lapsi puhui omasta toiminnastaan äitinsä näkökulmasta mm. käyttämällä itsestään yksikön toista persoonaa (your, you). Lapsi kuitenkin alkoi myöhemmin "käyttää pronomineja oikein", kuten Kanner (Kanner, 1943, s. 222) asian ilmaisee.

Myös muiden autismikirjon lasten on havaittu käyttävän itsestään yksikön toista persoonaa (Kanner, 1943, s. 223, 238; TagerFlusberg ym, 2005, s. 347). "Väärän” persoonan käyttö voi ilmetä lasten kaikupuheessa eli ekolaliassa. Kaikupuheessa lapsi toistelee kuulemiaan sanoja ja lausumia joko heti tai myöhemmin. Kaikupuhetta esiintyy sekä tyypillisesti kehittyvillä että autismikirjon lapsilla, mutta se on autismikirjon lapsilla tavallisempaa ja sitä vaikeampaa, mitä enemmän autistinen lapsi on. (Ks. esim. Tager-Flusberg 2005, 346.) Laajemman määritelmän mukaan kaikupuheeseen sisältyy monenlaista esittävää puhetta (ks. esim. Dornelas \& Pascual, 
2016). Kaikupuheessa ja epätavanomaisessa persoonapronominien käytössä ajatellaan olevan kyse laajemminkin siitä, että lapsen on hankala "vaihtaa näkökulmaa -- ja asettaa itseään ja puhekumppaniaan vaihteleviin keskustelurooleihin puhujana ja kuulijana" (Pentikäinen 2007, s. 22; ks. Tager-Flusberg ym., 2005, s. 347). Kaikupuhe voi kuitenkin olla tärkeä vuorovaikutusresurssi autismikirjon lapsille (Sterponi \& Shankey, 2014). Tämän tutkimuksen kohteena ovat aikuiset, ja tutkimus keskittyy kaikupuheen sijaan kuvitellun ajatuksen referointiin eli tilanteisiin, joissa tarkasteltavaa vuoroa edeltävä konteksti ei anna mallia tutkittavan tuottamalle puheelle.

\section{AINEISTO JA MENETELMÄ}

Tutkimusaineistomme on peräisin Suomen Akatemian rahoittamasta hankkeesta Pragmatic language abilities in adolescents and young adults with autism spectrum disorder, jonka yhteydessä kerättiin useita kommunikaation kehitystä ja sosiaalisia taitoja mittaa-

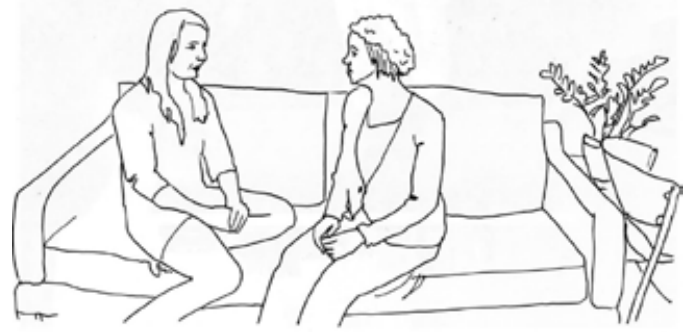

KUVA 1

Tässä tutkimuksessa osallistujat katselivat videon, jolla kaksi naista keskustelee toisen aloittamasta uudesta harrastuksesta (kuva 1). Videon lopussa harrastuksestaan kertonut nainen poistuu, ja huoneeseen jänyt nainen avaa tietokoneensa ja sanoo "pitääpä guuglettaa" (kuva 2). via osa-aineistoja, jotka videoitiin. Kyseinen hanke on osa Oulun yliopistollisen sairaalan (OYS) lastenpsykiatrian vastuualueella meneillä olevaa monitieteistä tutkimusta, jossa seurataan autismikirjon henkilöitä lapsuudesta aikuisuuteen. Pohjois-Pohjanmaan sairaanhoitopiirin eettinen toimikunta on hyväksynyt tutkimuksen.

Osallistujina tämän tutkimuksen otoksessa on 56 mies- ja naispuolista 19-29-vuotiasta henkilöä, joista 26:1la on lapsuudessa diagnosoitu autismikirjon häiriö osana aikaisempaa autismikirjon tutkimusta (ks. esim. Mattila ym., 2007; Kuusikko ym., 2008) tai heidät on rekrytoitu OYS:n kliinisestä potilasaineistosta osaksi seurantatutkimusta. Verrokkiryhmään kuuluvilla 30 puhujalla autismikirjon diagnoosia ei ole. Myös he ovat osallistuneet aikaisempiin seurantutkimuksen vaiheisiin (Kuusikko ym., 2008). Tämän tutkimuksen yhteydessä varmistettiin WAIS-patteristoa käyttäen, että kaikkien osallistujien kognitiivinen suoriutuminen oli normaalin vaihtelun rajoissa tai sen yli.

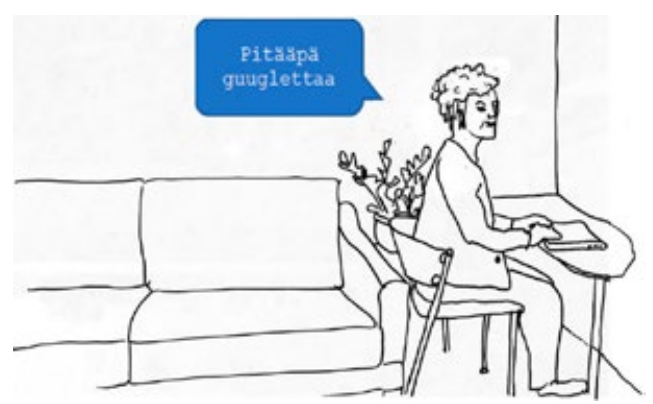

KUVA 2

Videon päätyttyä tutkija esittää tutkittavalle videoon liittyviä kysymyksiä, joista yksi koskee huoneeseen jääneen naisen ajatuksia. Kysymys on eri tutkittaville hieman erimuotoinen (esimerkit 1 ja 2). 


\section{Esimerkki 1}

Tutkija: Mitä tämä aattelee

\section{Esimerkki 2}

Tutkija: No mitä tummatukkane henkilö ajattelee

Aineistomme koostuu vastauksista, joita tutkittavat esittävät tähän kysymykseen. Tarkastelemme näitä vastausvuoroja tukeutuen kielen- ja keskusteluntutkimuksen käsitteistöön ja pyrkimällä hahmottamaan, millaisia kielellisiä rakenteita ja puhetoimintoja tutkimuksen osallistujien vastauksissa ilmenee. Puhetoiminnolla tarkoitamme sitä, mitä vuorolla tehdään keskustelussa. Karkeasti ottaen aineisto jakaantuu puhetoiminnoiltaan kahdenlaisiin vuoroihin, joista toisissa kuvaillaan (esimerkki 3) ja toisissa esitetään (esimerkki 4) videolla näkyvän henkilön ajatuksia.

\section{Esimerkki 3 (kuvailu, verrokki)}

ilmeisesti hän kiinnostu (1.4) kiinnostu siitä kurssista?

Kuvailevalle vuorolle on tyypillistä näkökulman asettuminen puhehetkeen, mikä näkyy esimerkissä 3 hän-pronominin käyttönä ja aikamuotovalinnassa kiinnostu. Kolmannen persoonan pronomini hän viittaa puhetilanteen ulkopuolelle (kun taas 1. ja 2. persoona viittaisivat puhetilanteessa läsnäoleviin henkilöihin). Imperfektimuotoinen verbi puolestaan osoittaa, että puhuja käsittelee tapahtumaa toisessa ajassa tapahtuneena. Nämä kielelliset valinnat ilmaisevat eroa meneillään olevan puhetilanteen ja referoidun tilanteen osallistumiskehikon ja tapahtuma-ajankohdan välillä. Puhuja siis huomioi sanavalinnoillaan sen, että on paraikaa tutkimustilanteessa, vaikka kuvaileekin toista tilannetta.

\section{Esimerkki 4 (esitys, autismikirjon henkilö)}

p’tää hakea lisää tietoa että ymmärrän aihetta paremmin

Esittävä vuoro (esimerkki 4) puolestaan on esitetty referoitavan henkilön äänellä, mikä näkyy esimerkissä 4 yksikön 1. persoonan ja preesensin (pitää, ymmärrän) käyttönä. Vaikka puhuja käyttää 1. persoonaa (ymmärrän), hän ei puhu omasta ymmärryksestään. Myöskään preesensmuoto ei tarkoita tässä, että ymmärtäminen (tai pitäminen) tapahtuisi puhetilanteessa eli tutkimuskeskustelussa. Vuoron ilmaisema 'minä' on videon henkilö ja ajankohta videon tapahtuma-aika. Puhuja siis kuvitteellisesti siirtyy meneillään olevasta puhetilanteesta referoitavaan tilanteeseen ja matkii siinä esiintyvän henkilön oletettuja ajatuksia.

Vastauksia tarkasteltaessa on huomioitava, etteivät tutkijan kysymysvuorot ohjaa vastaajia sen paremmin kuvailun kuin esittämisenkään suuntaan: Tutkijat viittaavat videon henkilöön 3. persoonassa (meneillään olevan puhetilanteen näkökulmasta) mutta preesensmuodossa (videon tilanteen näkökulmasta). Seuraavassa luvussa kerromme tarkemmin toisen henkilön ajatusten kuvailusta ja esittämisestä aiemman tutkimuksen ja oman aineistomme valossa. Luvun 4.1 lopussa täsmennämme myös aineiston luokitteluperusteita.

\section{TOISEN HENKILÖN AJATUSTEN KUVAILU JA ESITTÄMINEN}

Tämän tutkimuksen taustalla on puheaktiteoriasta (Austin, 1962; Searle, 1969; vrt. Bühler, 2011, s. 57-66) alkunsa saanut ja keskustelunanalyysissa (ks. esim. Heritage \& Atkinson, 1984) vallitseva ajatus siitä, että keskustelussa puhujien vuorot ovat luonteeltaan sosiaalista toimintaa. Kullakin vuorolla 
tehdään yksi tai useampi sosiaalinen teko, joita tässä nimitämme puhetoiminnoiksi. Puhetoimintoja voivat olla esimerkiksi vastaaminen, kuvailu ja esittäminen. Tärkeä menetelmällinen kysymys koskee toimintojen määrittelyä: määritteleekö tutkija ennalta toiminnot, joihin aineisto sijoitetaan, vai määritelläänkö toiminnot kielellisten piirteiden perusteella tai kenties keskustelun kulkua tarkastelemalla.

Keskustelunanalyyttisessa tutkimuksessa pyritään välttämään ennalta määriteltyjä kategorioita, ja arkikeskustelujen tutkimuksessa puhetoimintoja onkin määritelty sen perusteella, millaisen reaktion puhujan vuoro saa (Sacks, Schegloff \& Jefferson, 1974). Kyseinen tutkimustapa ei kuitenkaan palvele tätä tutkimusta. Tässä tutkimamme aineisto on haastattelutyyppinen tutkimustilanne, jossa tutkijan reaktiot ovat hyvin samankaltaisia riippumatta siitä, miten haastateltava on vastannut. Emme siis voi tutkijan reaktion perusteella päätellä, tulkitsiko tämä edeltävän vuoron esitykseksi vai kuvailuksi vai joksikin muuksi. Siksi määrittelemme vuoroilla tehtävät toiminnot vuoroista itsestään käsin tukeutumalla aiempaan tutkimukseen ja oletukseen, että eri tavoin kielennetyt vuorot edustavat eri puhetoimintoja. Tarkastelemme aineistoa laadullisesti analysoimalla, miten esittävät vuorot rakentuvat. Tutkimuksessa kuvailemme tarkemmin vastausten ominaispiirteitä erityisesti niissä ilmenevien puhetoimintojen kannalta sekä kuvaamme vastausten jakaantumista autismikirjon henkilöillä ja verrokeilla.

\subsection{Kuvailu ja esittäminen pubetoimintoina}

Tarkastelemme kuvailua ja esittämistä deiksiksen kannalta. Deiktisellä origolla tarkoitetaan aikaa, paikkaa ja puhujaa, jonka näkökulmasta asia esitetään (Bühler, 2011 [1934],
VISK \$1424). Kuvailulle on tyypillistä deiktisen origon asettuminen puhehetkeen, kun taas esitys lausutaan referoitavan henkilön näkökulmasta. Deiktisen origon määrittäviä piirteitä, kuten tässä persoonaa ja aikamuotoja, kutsumme deiktisiksi markkereiksi (engl. deictic markers).

Toisin kuin kuvailussa, esityksissä tapahtuu ns. deiktinen siirtymä (engl. deictic shift), jonka myötä puhuja ikään kuin siirtyy pois meneillään olevasta puhetilanteesta ja ottaa näkökulman, joka kuuluu toiseen aikaan ja paikkaan - ja tässä tapauksessa myös toiselle puhujalle (ks. esim. Bakhtin, 1982 [1934]; Volosinov, 1973). On kuitenkin huomioitava, ettei siirtymä ole todellinen eikä täydellinen, vaan puhe on aina viime kädessä tuotettu meneillään olevaa puhetilannetta varten (Clift \& Holt, 2006; Volosinov, 1973). Puhuja voi "lainata" esitykseen piirteitä jostakin toisesta - todellisesta tai kuvitellusta - puhetilanteesta tai vaikkapa toisen henkilön oletetuista ajatuksista, kuten aineistossamme, mutta esitys palvelee kuitenkin aina meneillään olevaa puhetilannetta. Aineistossamme esitykset aivan kuten kuvailukin siis toimivat ensi kädessä vastauksina tutkijan esittämään kysymykseen. Kyse on puhetoimintojen päällekkäisyydestä eli siitä, että vuoro toimii samanaikaisesti sekä vastauksena että kuvailuna tai esityksenä.

Suomen kielessä on ainakin 11 tapaa ilmaista toisen henkilön puhetta tai ajatusta (Kuiri, 1984, s. 1). Näitä tapoja kutsutaan yleisesti referoinniksi. Tässä tutkimuksessa käytämme referoinnin käsitettä kattoterminä, joka käsittää sekä kuvailun että esittämisen puhetoiminnot. Käytämme käsitettä referaattiosa tarkoittamaan referoinneissa esiintyvää toisen henkilön äänellä sanottua osuutta vuorosta. Referointitilanteella tarkoitamme meneillään olevaa puhetilannetta (tässä tapauksessa tutkimushaastattelua), jossa tapahtuu referointia. Referoitava tilanne on puolestaan se tilanne, olemassa oleva tai kuviteltu, josta 
puhujat keskustelevat - tässä tapauksessa siis videolla näkyvä puhetilanne.

Tässä tutkimuksessa käytämme johtolauseen käsitettä tarkoittamaan kaikkia referaattiosaa kehystäviä ilmaisuja. Niitä ovat esimerkiksi ajattelua ilmaisevan verbin sisältämä se nyt miettii että, puhekielessä vakiintunut oli sillee että sekä tunnetta kuvaava innostu tavallaa että. Puhutussa kielessä tavataan myös johtolauseettomia referointeja, joissa referaattiosaa kehystää pelkkä että- tai jottakonjunktio tai esimerkiksi partikkeli ni(in), konjunktio $j a$ tai puhujan toiminnan kuvaus, kuten sehän tuli (Kuiri, 1984, s. 149-162). Johtolauseeton referointi on harvinaista: se muodostaa esimerkiksi Kuirin tutkimissa murrehaastatteluissa vain noin $3 \%$ kaikista referoinneista. Arkikeskustelujen pitkissä kertomusjaksoissa on havaittu johtolauseetonta referointia tilanteissa, joissa samoja kertomushahmoja referoidaan useampaan otteeseen ja referointi merkitään esimerkiksi äänensävyn muutoksella (ks. Haakana, 2005; Priiki, 2014).

Emme käytä tässä tutkimuksessa perinteisiä käsitteitä suora, epäsuora ja vapaa suora esitys (ks. esim. VISK \$1460). Suomenkielisistä puhutuista aineistoista tehdyt tutkimukset ovat nimittäin osoittaneet, että tällaista selkeää jakoa ei todellisuudessa esiinny (VISK \$1459; Haakana, 2005, s. 119; Priiki, 2014). Esimerkiksi perinteisesti epäsuoran esityksen merkkinä pidettyä että-partikkelia käytetään suomenkielisissä keskusteluissa lähes kaikenlaisessa referoinnissa (Penttilä, 1948, s. 54-56; Routarinne, 2005, s. 97; VISK \$1465). Puhujan käyttämät deiktiset markkerit saattavat myös olla ristiriitaisia tai epäselviä kuten esimerkissä 5 .

\section{Esimerkki 5 (autismikirjon henkilö)}

kaiketi miettii että millaistahan se oli se (.) mikä se kurssi
Esimerkki 5 sisältää johtolauseen kaiketi miettii, joka implikoi videolla näkyneen henkilön mentaalista toimintoa. Johtolausetta seuraa että-partikkeli, joka on kuulijalle merkki siitä, että referaattiosa on alkamassa (esim. Laury \& Seppänen, 2008). Tämän jälkeen tulee referaattiosa millaistahan se oli se (.) mikä se kurssi. Referaattiosa sisältää -hanpartikkelin, joka voi olla deiktinen markkeri, mutta joka ei kuitenkaan eksplisiittisesti siirrä deiktistä origoa pois meneillään olevasta puhetilanteesta. Myös imperfekti on aikamuotona sellainen, että se tässä tapauksessa tulee kyseeseen sekä siinä tapauksessa, että äänessäolija puhuu omasta näkökulmastaan, että jos hän puhuu videolla olevan henkilön näkökulmasta.

Esimerkissä 5 on siis sekä kuvaileva johtolause että referaattiosa, jonka voi ajatella olevan joko kuvailun jatkoa tai esitys. Laskiessamme toisen henkilön ajatuksen kuvailun ja esityksen märiä aineistossa erotimme omaksi ryhmäkseen a) kuvailun, b) esityksen sekä c) neutraalit vuorot. Esimerkki 5 on laskettu neutraaleihin vuoroihin, sillä vaikka siinä oleva johtolause (kaiketi miettii) on luonteeltaan kuvaileva, itse referaattiosasta ei voida sanoa, onko se kuvailua vai esitystä. Vuoroa ei tässä tutkimuksessa ole laskettu kuvailuksi, koska puhuja ei johtolauseessa kuvaile toisen henkilön ajatuksia vaan ainoastaan sitä, että tämä ajattelee. Toisaalta vain sellaiset vuorot, joissa deiktinen origo siirtyy selvästi pois meneillään olevasta puhetilanteesta, on laskettu esitykseksi (esimerkki 6).

\section{Esimerkki 6 (autismikirjon henkilö)}

kuulostaapa tosi hauskalta kurssilta haluanpa itsekin mukaan sinne .hhh olisi mukava saada vähän piristystä omaankin kämppään 
Esimerkissä 6 olevaa -pa-partikkelia emme laskeneet varmaksi merkiksi deiktisen origon siirtymisestä pois meneillään olevasta puhetilanteesta, kuten emme esimerkin 5 -hanpartikkeliakaan. Esimerkissä 6 on kuitenkin käytetty myös yksikön 1. persoonaa haluanpa sekä pronominia itse ja adjektiivia oma, minkä vuoksi se on laskettu esitykseksi. Jatkamme keskustelua esittävien vuorojen rakentumisesta luvussa 5. Ensin tarkastelemme kuitenkin vuorojen määrällistä jakautumista.

\subsection{Vastausten jakautuminen}

Aineiston 56 vastausvuorosta löytyi yhteensä 67 puhetoimintoa eli kuvailun, esityksen tai neutraalin toiminnon esiintymää. Mikäli moniosaisessa vuorossa oli useampi kuin yksi puhetoiminto, se laskettiin kahteen eri ryhmään kuuluvaksi, mistä johtuen puhetoimintoja on aineistossa enemmän kuin vastausvuoroja. Luokittelimme vastaukset kuvailuihin, esityksiin ja neutraaleihin vuoroihin (Kuvio 2).

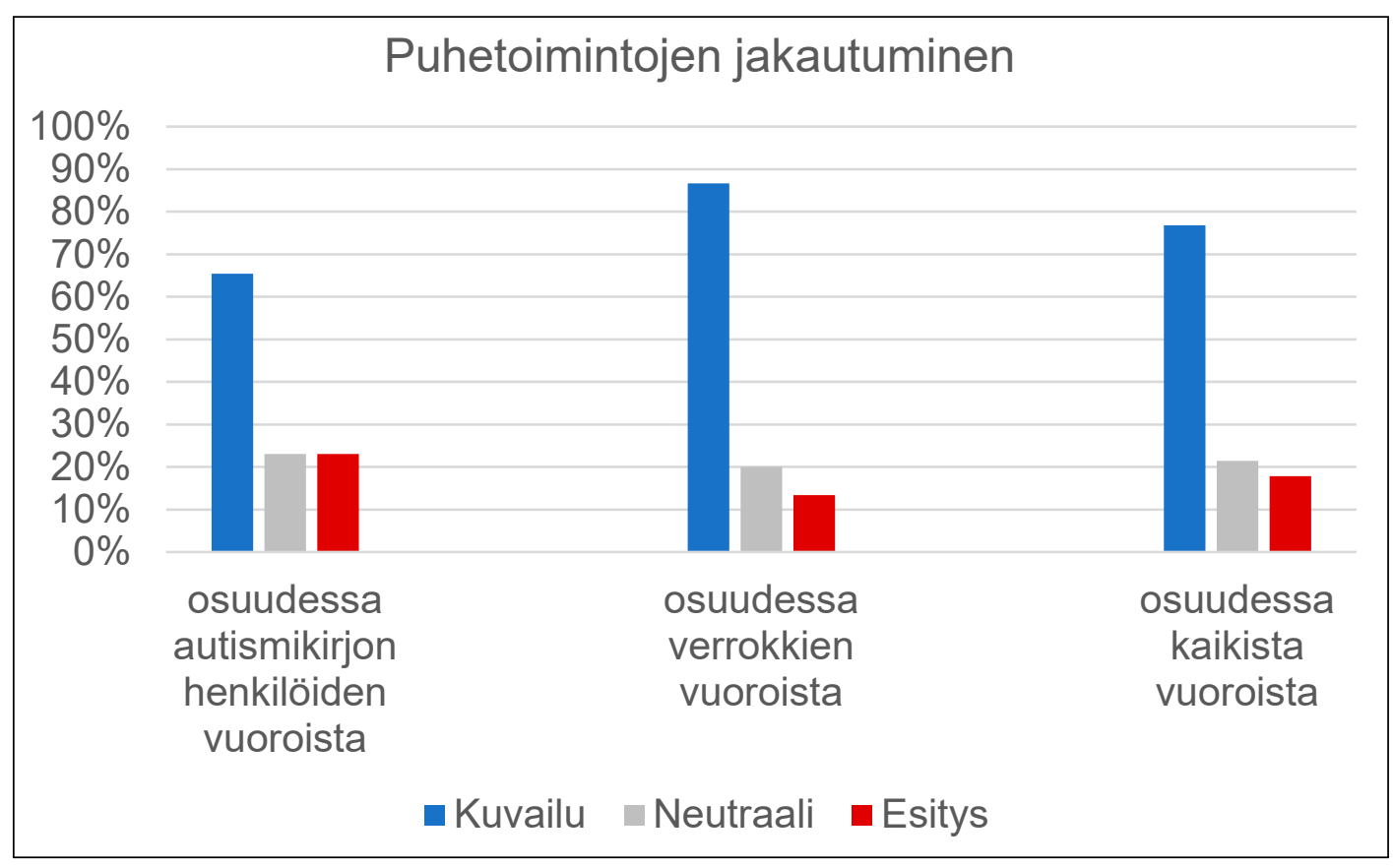

KUVIO 2. Puhetoimintojen jakautuminen

Kuviossa 2 on esitetty, kuinka suuri osa autismikirjon henkilöiden ja verrokkien vuoroista sisältää mitäkin puhetoimintoa (kuvailua, esitystä ja neutraaleja puhetoimintoja) ${ }^{1}$. Kuviosta nähdään, että kuvailu on yleisin toiminto molemmissa ryhmissä, mutta sen osuus on suurempi verrokeilla kuin autismikirjon henkilöillä, joiden vuoroissa on puolestaan

1 Koska puhetoimintoja saattoi olla useampi yhdessä vuorossa, niiden yhteenlaskettu lukumäärä ylittää 100 $\%$ vuoroista. suhteessa enemmän esityksiä kuin verrokeilla. Siinä, missä $87 \%$ verrokkien vastauksista sisältää kuvailua, vastaava luku on autismikirjon henkilöillä vain $65 \%$. Eri toimintojen lukumäärät kummankin ryhmän vuoroissa on esitetty Taulukossa 1, josta näemme myös, että kyse on varsin pienistä lukumääristä neutraalien puhetoimintojen ja esityksen osalta. Ryhmien välisiä eroja voidaan tästä syystä pitää korkeintaan suuntaa-antavina. 
TAULUKKO 1. Kuvailun ja esityksen lukumäärät autismikirjon henkilöillä ja verrokeilla.

\begin{tabular}{ll|l|l}
$\begin{array}{l}\text { Puhetoimintoja sisältäviä } \\
\text { vastauksia }\end{array}$ & $\begin{array}{l}\mathrm{kpl} \\
\text { autismikirjon } \\
\text { henkilöt }\end{array}$ & $\begin{array}{l}\text { kpl } \\
\text { verrokki-henkilöt }\end{array}$ & kpl yhteensä \\
\hline Kuvailu & 17 & 26 & 44 \\
Neutraali & 6 & 6 & 13 \\
Esitys & 6 & 4 & 10 \\
\hline Yhteensä & 29 & 38 & 67
\end{tabular}

Aineiston valossa vaikuttaa siltä, että verrokit käyttävät keskimäärin hieman enemmän toisen henkilön ajatusten kuvailua kuin autismikirjon henkilöt ${ }^{2}$. Kuvailu eroaa esityksestä siten, että se esitetään meneillään olevan puhetilanteen näkökulmasta esimerkiksi nimeämällä videolla esiintyvän henkilön ajatuksia ja tunteita. Tyypillinen kuvaileva vastaus aineistossamme sisältää verbin kiinnostaa (esim. No ehkä sitäki alko kiinnostaan se kurssi). Yhteensä 37 vastausta (14 autismikirjon henkilöllä ja 23 verrokilla) sisältää tämän verbin tai siitä johdettuja sanoja kiinnostua, kiinnostava ja kiinnostunut. Ottaen huomioon, että kuvailevia vuoroja oli yhteensä 44, tämä joukko käsittää valtaosan vastauksista. Kolme autismikirjon henkilöä ja neljä verrokkia arvelee, että videon henkilö haluaa osallistua puheena olleelle kurssille. Muita kuvailuissa käytettyjä tunteiden nimityksiä ovat innoissaan, innostunut ja belpottunut.

Esityksiä on aineistossa vain 10 , mutta ne ovat varsin monimuotoisia, minkä vuoksi käsittelemme niitä tarkemmin seuraavassa luvussa.

2 Tämän tutkimuksen pieni otos ei kuitenkaan tuo esiin tilastollisesti merkittäviä eroja eri puhujaryhmien välillä, vaan määrällisten erojen selvittäminen vaatisi suuremman aineiston.

\section{ESITTÄVIEN VUOROJEN RAKENTUMINEN}

Aineistomme 10:ssä vuorossa tapahtuu deiktinen siirtymä, eli puhuja esittää osan puheestaan ikään kuin toisesta tilanteesta käsin. Siirtymät näkyvät siinä, että vuoron aikana deiktinen origo pysyy osan aikaa meneillään olevassa puhetilanteessa ja siirtyy osaksi aikaa siitä pois. Aineistossa on yhteensä viisi esimerkkiä, joiden olemme tulkinneet sisältävän sekä kuvailevan että esittävän osan, ja ne onkin edellisen luvun laskelmissa huomioitu molemmissa kategorioissa. Lisäksi on yksi esimerkki, jossa esitys yhdistyy neutraaliksi tulkittavaan osaan.

Deiktiset siirtymät ovat monesti hyvin hienovaraisia. Esimerkki 7, jonka tulkitsemme sisältävän sekä kuvailevan että esittävän osan, osoittaa, ettei "esitys" ole toimintona selvärajainen, vaan vuoro voi sisältää joko vähän tai enemmän sellaisia piirteitä, jotka tekevät siitä esityksen kaltaisen (ks. myös Clark \& Gerric, 1990).

\section{Esimerkki 7 (verrokki)}

no se nyt miettii että missä ihimeessä se muka käy hhh. Ottaa selevää siittä missä se toinen käy 
Esimerkissä 7 on kuvaileva johtolause no se nyt miettii, jota seuraa että-partikkeli ja referaattiosamissä ibimeessäsemukakäy. Referaattiosan voi tulkita esitykseksi preesensmuodon käy ja missä ibmeessä- ja muka-sanojen vuoksi, jotka osoittavat eläytymistä referoidun henkilön näkökulmaan. Vaikutelmaa korostaa erittäin voimakas painotus ihimeessä-sanan alussa. Referaattiosan jälkeen deiktinen origo palaa meneillään olevaan puhetilanteeseen puhujan siirtyessä kuvailuun: Ottaa selevää siittä missä se toinen käy.

Tässä esimerkissä puhuja käyttää esitystä kohdassa, joka koskee referoidun henkilön ajatuksia (miettii), ja kuvailua kohdassa, jossa kertoo henkilön toiminnasta (ottaa selevää). Esityksen käyttäminen juuri referaattiosassa on perusteltua toisaalta siksi, että se asettaa kohosteiseen asemaan juuri sen osan vuoroa, joka vastaa tutkijan varsinaiseen kysymykseen, ja toisaalta tietenkin siksi, että esitys on tavanomainen tapa ilmaista toisen henkilön ajatuksia. Esimerkissä 8 deiktiset siirtymät ovat selvempiä kuin esimerkissä 7 , ja niitä on useampi.

\section{Esimerkki 8 (verrokki)}

se oli varmaa (.) iha (.) aidosti (.) tai se oli (.) mun mielestä se oli ihan innoissaan kans siitä ja oli sillee että vau kuulostaa kivalta ja (.) *että* Varmaa niinku innostu tavallaa että no, Hei tuohan vois olla siistiä

Esimerkki 8 alkaa kuvailulla, jota seuraavat johtolause oli sillee (ks. VISK \$1487), siirtymää merkitsevä partikkeli että ja referaattiosa. Referaattiosan voi tulkita esitykseksi preesensmuodon kuulostaa perusteella, ja tulkintaa vahvistaa innostusta ilmaiseva huudahduspartikkeli vau (ks. VISK \$856, \$1489), jolla puhuja ilmaisee asettautumista referoitavan henkilön asemaan. Tätä seuraavat rinnastuskonjunktio ja ja hiljaa lausuttu että-sana, joka ei kuitenkaan aloita referaattiosaa vaan siirtymän takaisin kuvailuun. Partikkeliketju että no hei (VISK \$1489) ilmaisee siirtymää toiseen esitykseen tuohan vois olla siistiä. Deiktinen siirtymä on nähtävissä demonstratiivipronominista tuo ja referaattiosan rajalla olevasta hei-partikkelista, joka tässä ilmaisee puhujan havaintoa tai oivallusta (ks. VISK $\$ 858$ ja $\$ 1029)$.

Esimerkki 9 on ainoa autismikirjon henkilön tuottama vuoro, jossa on sekä kuvailua että esitystä.

\section{Esimerkki 9 (autismikirjon henkilö)}

mitä sitte aikooki googlettaa (0.5) öö (.) ellei se sitte niinko mm yritä esittää niinko oo kiinno- o- .hhh aa sanotaa kiinnostuneempaa ko onkaa ja siinä tappauksesa nii se miettii että no minkä (0.6) no sen sijasa miettisi että minkäkähä hakusanan tähä pistäsi että nii .hhh ää tullee sentää tehtyä mitä sano

Esimerkki 9 alkaa sekin kuvailulla, jossa puhuja arvelee, että videon henkilö saattaisi 'esittää kiinnostuneempaa kuin onkaan'. Tämä kuvaus sisältää arvion, ettei videon henkilö olisi aidosti kiinnostunut puheena olleesta aiheesta. Tämän kaltainen vastaus oli kolmella autismikirjon henkilöllä ja kolmella verrokkiryhmään kuuluvalla vastaajalla. Tämä taustoitus päättyy johtolauseeseen se miettii että, joka kehystää sanoilla no minkä alkavaa referaattiosaa. Referaattiosa kuitenkin katkeaa taukoon ja johtolauseen korjaukseen sen sijasa miettisi, joka kääntää johtolauseen merkityksen päinvastaiseksi. Näin ollen puhuja ilmaisee, että johtolausetta seuraava referaattiosa minkähän hakusanan tähän pistäisi ilmaisee ajatusta, jota videon henkilö voisi ajatella mutta todennäköisesti ei ajattele.

Esimerkin 9 referointiosa minkähän hakusanan tähän pistäisi on esitys, jossa selvin 
deonttista siirtymää ilmaiseva markkeri on demonstratiivipronomini tähän, joka viittaa videolla olevan henkilön edessä olevaan tietokoneeseen. Referaattiosassa on käytetty geneeristä kolmatta persoonaa (ns. nollapersoonaa), jolla käytetään usein puhujan omaa näkökulmaa ilmaisemaan eli yksikön 1. persoonan merkityksessä (VISK $\$ 1347, \$ 1362$; Laitinen, 1995; Varjo 2019). Kolmannen persoonan käyttö jatkuu vuoron loppuun asti ulottuvassa referaattiosassa tullee sentää tehtyä mitä sano. Tämäkin on tulkittava geneeriseksi lauseeksi persoonapronominin puuttumisen ja passiivisen partisiipin tehtyä vuoksi. Mikäli lause olisi merkitykseltään 3. persoonainen, se olisi todennäköisemmin aktiivissa (esim. hän tulee tehneeksi) - vaikkei tulkinta ?hänen tulee tehtyä aivan mahdoton ole sekään.

Edellä käsitellyt esimerkit osoittavat, miten deonttiset siirtymät - eli siirtymät kuvailusta esitykseen ja takaisin - voivat olla joko melko selviä taikka hyvinkin asteittaisia, osittaisia ja tulkinnanvaraisia. Tämä epämääräisyys on myös kielenkäyttäjän etu: puheeseen voi tuoda moniäänisyyttä siten, että läsnä on samanaikaisesti useampi tilanne, puhuja ja kuulija. Puhuja voi siis tuoda meneillään olevaan puhetilanteeseen kaikuja toisesta tilanteesta ja lisätä omaan puheeseensa häiveitä toisen puhujan äänestä. Samalla säilytetään kuitenkin yhteys meneillään olevaan puhetilanteeseen. Siinä missä vuorojen esittävät osiot tekevät referoitavan videon tilanteen eläväksi, kuvailevat osiot huomioivat meneillään olevan tutkimustilanteen ja läsnä olevan vastaanottajan. Kuvaileva puhe pitää siis ikään kuin enemmän etäisyyttä referoitavaan tilanteeseen: videon henkilö on etäinen hän tai se ja tutkimustilanteen haastateltava ja tutkija puolestaan aktiivisia ja läsnä olevia osallistujia ja äänessäolijoita.

Vastauksissa on kuitenkin myös vuoroja, joissa ei ole mukana lainkaan kuvailua. Kaikki nämä neljä vastausta (esimerkit 10-13) ovat autismikirjon henkilöiltä, mikä voi näin pienessä aineistossa olla sattumaakin. Esimerkissä 10 esitystä edeltää että-sana, joka esiintyy suomen puhekielen johtolauseettomissakin referoinneissa ilmaisemassa referaattiosan alkua (Kuiri, 1984, s. 149-152; Lappalainen, 2019; VISK \$1486, \$1488).

\section{Esimerkki 10 (autismikirjon henkilö)}

Tutkija: No mitä tämä aattelee.

Haastateltava: mt että: (.) että onpa $\mathrm{j}(\mathrm{h})$ ännä he he hh

Aiemmin on tutkittu referointia luonnollisissa keskustelutilanteissa ja murrehaastatteluissa, joissa on pitkiä kerrontajaksoja. Näissä yhteyksissä johtolauseetonta referointia ilmenee yleensä kohdissa, joissa referoidaan dialogia ja joissa referoitava henkilö on jo kertaalleen nimetty (Kuiri, 1984, s. 153; Lappalainen, 2019; Priiki, 2014; VISK \$1488). Nyt käsiteltävässä aineistossa referoitava henkilö on ilmaistu kysymysvuoroissa, joiden kanssa tutkimamme vastausvuorot muodostavat vierusparin. Sen lisäksi, että kysymyksissä on ilmaistu puheena oleva henkilö, niissä on lausuttu ääneen myös toiminta, jota kysytään: ajattelu. Koska johtolauseille tyypilliset elementit on mainittu jo vierusparin etujäsenessä, niitä ei ole tarpeen toistaa jälkijäsenessä.

Aivan kuten referoinnissa yleensäkin, partikkeli että muodostaa esimerkissä 10 "sillan", joka ilmaisee deonttista siirtymää (ks. Frick 2013, s. 51-52; Laury \& Seppänen, 2008). Esimerkissä 10 siirtymä on kuitenkin kahden eri puhujan vuorojen välillä: siinä missä kysyjä esittää kysymyksen meneillään olevan puhetilanteen kehyksessä, vastaaja ilmaisee että-partikkelilla siirtävänsä deonttisen origon pois siitä. Referaattiosassa onpa jännä deonttisina markkereina toimivat $p a$-liitepartikkeli ja nau- 
rava äänensävy. Äänensävyn muutos onkin ominaista erityisesti johtolauseettomille referoinneille (Priiki 2014; VISK \$1488).

Esimerkki 11 on aiemman tutkimuksen valossa poikkeuksellisempi referointi, sillä siinä ei ole lainkaan johtolausetta eikä referaattiosaan johdattelevaa että-partikkelia. Vuoro sisältää kuitenkin pieniä elementtejä, jotka sitovat sen meneillään olevaan puhetilanteeseen.

\section{Esimerkki 11 (autismikirjon henkilö)}

ahah ahah (0.5) joo (.) sitte, @hittokominä en tiiä asiasta minäpä pistän@ö- lö-pistän $£$ kuukl(h)een ja .hh £mitäpä suuri tietäjä kuukle tietää $£$ he he

Esimerkki 11 alkaa sanoilla ahab ahah ja joo, joista ei voi varmaksi sanoa, onko deonttinen origo niiden aikana meneillään olevassa vai referoitavassa tilanteessa, eli ovatko ne puhujan omalla äänellä esitettyjä vai esitystä. Niitä seuraava sana sitte sitoo vuoron kuitenkin selvästi meneillään olevaan puhehetkeen. Sana sitte ohjaa tulkintaan, että jokin osa edeltävistä sanoista oli referointia ja että referointia on luvassa myös seuraavaksi. Seuraa pitkähkö esitys, jonka aikana puhuja ensin muuttaa äänensävyään ja lopuksi myös hymyilee sanan kuukleen kohdalla. Yksikön 1. persoonan pronomi minä ja preesens ovat deonttisia markkereita, jotka ilmaisevat deonttisen origon olevan referoitavassa puhetilanteessa. Sana ja tuo origon hetkeksi meneillään olevaan puhetilanteeseen ja on merkitykseltään samankaltainen kuin aiempi sitte. Nämä kaksi sanaa ilmaisevat, että puhuja ikään kuin listaa vastauksia tutkijan kysymykseen - eli videolla näkyvän henkilön ajatuksia. Näistä ajatuksista viimeinen on hymyillen lausuttu ja päättyy nauruun.
Siinä missä äänensävyn muutos@hittoko... toimii deonttisena markkerina, joka sitoo sanotun referoitavaan tilanteeseen, hymy $£ m i$ täpä... ja nauru ovat ikään kuin puhujan omaa kannanottoa sanottuun. Samalla kun hän esittää videolla näkyvän henkilön puhetta, hän voi hymyllä ja naurulla tuoda esiin myös oman näkökulmansa eli sen, että sanottu on jollain tapaa ei-vakavaa tai hauskaa. Tällainen limittyminen on referoinnille tyypillistä: sen lisäksi, että puhujat näennäisesti liikkuvat referoitavan ja meneillään olevan puhetilanteen väliä deonttisten siirtymien avulla, he aktivoivat myös samanaikaisesti molempien tilanteiden piirteitä (ks. Clark \& Gerric, 1990).

Aineistossa on myös kaksi esimerkkiä, esimerkit 12 ja 13, jotka eivät sisällä lainkaan sellaisia kielellisiä elementtejä, jotka sitoisivat ne meneillään olevaan puhetilanteeseen. Kutsumme niitä siitä syystä "paljaiksi esityksiksi". Nämäkin esimerkit ovat molemmat autismikirjon henkilöiltä.

\section{Esimerkki 12 (autismikirjon henkilö)}

(5.0) p'tää hakea lisää tietoa että ymmärrän aihetta paremmin

Esimerkki 12 alkaa pitkällä tauolla, joka asettuu tutkijan kysymyksen ja haastateltavan vastauksen väliin. Tauko saattaa kieliä prosessoinnista eli siitä, että haastateltava miettii, miten vastaisi kysymykseen. Itse vastaus on paljas esitys, jossa käytetyt yksikön 1. persoona ja preesensmuoto asettavat deiktisen origon selvästi referoitavaan tilanteeseen. Esimerkki 13 on laajempi vastaus kuin esimerkki 12, mutta siinäkään ei ole elementtejä, jotka sitoisivat sen meneillään olevaan puhetilanteeseen. 


\section{Esimerkki 13 (autismikirjon henkilö)}

kuulostaapa tosi hauskalta kurssilta haluanpa itsekin mukaan sinne .hhh olisi mukava saada vähän piristystä omaankin kämppään

Esimerkki 13 käsiteltiin jo aiemmin esimerkkinä 6. Siinä yksikön 1. persoona ja preesensmuoto ilmaisevat deiktisen origon asettumista referoitavaan tilanteeseen. Lisäksi esimerkissä käytetyt -pa-liitepartikkeli ja sanat itse ja oma korostavat tätä vaikutelmaa.

Haastattelutyyppisessä tutkimuskeskustelussa, jossa vierusparin etujäsenenä toimiva kysymys on esitetty meneillään olevan tilanteen näkökulmasta, voi analyysimme perusteella sanoa olevan odotuksenmukaista sitoa myös vastausvuoro jollain tapaa meneillään olevaan tilanteeseen. Tämä on ylipäätään tyypillistä referoinnille: referointi palvelee aina meneillään olevaa puhetilannetta, mikä näkyy sen muotoilussa. Vähintään että-sana on suomenkielisissä referoinneissa tyypillisesti läsnä siltana, joka osoittaa, että puhuja on siirtymässä referaattiosaan (Penttilä, 1948, s. 54-56; Routarinne, 2005, s. 97; VISK \$1465). Sekä oman aineistomme että aiemman tutkimuksen valossa joidenkin autismikirjon henkilöiden tuottamat vastausvuorot - paljaiksi esityksiksi kutsumamme vuorot - jotka eivät sisällä lainkaan meneillään olevaan puhetilanteeseen sitovia elementtejä, ovatkin harvinaisia (haastatteluaineistoista esim. Kuiri, 1984, 154-160; Lappalainen 2019). Paljasta esitystä esiintyy jonkin verran arkikeskustelun pitkissä kertomusjaksoissa, joissa referoidaan toistuvasti samojen hahmojen dialogia tai ajatuksia (Haakana 2005; Priiki 2014).

\section{YHTEENVETO JA POHDINTAA}

Tässä tutkimuksessa tarkastelimme 26 autismikirjon henkilön ja 30 verrokin tutkimustilanteessa tuottamia vastauksia kysymykseen, joka koskee videolla nähdyn henkilön ajatuksia. Tutkijan kysymykset ovat tyyppiä mitä tämä ajattelee, ja tutkittavat vastaavat siihen joko kuvailemalla videolla esiintyvän henkilön ajatuksia tai esittämällä niitä. Moni vastauksista sisältää sekä kuvailua että esitystä, ja mukana on myös neutraaleja vastauksia, joita ei voi luokitella kuvailuksi tai esitykseksi. Käytämme referoinnin käsitettä kattamaan kaiken aineistossa esiintyvän toisen henkilön ajatuksen ilmaisemisen: kuvailun, esityksen ja neutraalit vuorot.

Tyypillistä kuvailua on videolla näkyvän henkilön ajatusten nimeäminen (esim. [häntä] kiinnostaa, [hän on] innostunut). Kuvailua oli suurimmassa osassa vastauksia sekä autismikirjon henkilöillä että verrokkiryhmässä, jossa sitä oli kuitenkin enemmän: verrokkiryhmän vastauksista $87 \%$ sisältää kuvailua, kun taas autismikirjon henkilöillä vastaava luku on $65 \%$. Havaitsemistamme lukumääristä ei voi tehdä kovin laajoja yleistyksiä, mutta ne ovat linjassa joidenkin aiempien tutkimusten kanssa, joissa on havaittu, että autismikirjon lapset ja aikuiset käyttävät verrokkeja vähemmän kognitiivisia toimintoja kuvaavia sanoja (Barnes ym., 2009; Tager-Flusberg 2005, s. 344). Kyse ei kuitenkaan ole täysin samasta asiasta, sillä myös esittävät toiminnot sisältävät kognitiivisia toimintoja merkitseviä sanoja. Kuvailevien vuorojen tarkempi analyysi jää tämän tutkimuksen ulkopuolelle, ja siihen olisi hyvä palata myöhemmissä tutkimuksissa. Tämä tutkimuksemme pureutuu tarkemmin esittävien vuorojen muotoon.

Siinä missä kuvailu tapahtuu meneillään olevan puhetilanteen näkökulmasta, esittävät vuorot sisältävät deonttisen siirtymän referoitavaan tilanteeseen, mikä ilmenee esim. 
yksikön 1. persoonan ja preesensmuodon käyttönä (esim. haluan, ymmärrän). Esitystä ilmeni suhteellisen vähän sekä autismikirjon henkilöillä että verrokkiryhmässä. Tutkimuksemme ohjaa havainnoimaan myös mahdollisia laadullisia ominaispiirteitä joidenkin autismikirjon henkilöiden referoinnissa.

Tutkimiemme esimerkkien valossa näyttäisi siltä, että verrokkiryhmän henkilöiden vastaukset sisältävät aina myös kuvailua silloinkin, kun mukana on esitystä. Näin on useimmilla autismikirjon henkilöilläkin, joskin joillakin autismikirjon henkilöillä on vastauksia, jotka sisältävät pelkästään esitystä. Nämä esitykset on joskus sidottu meneillään olevaan puhetilanteeseen esimerkiksi että-, sitten- ja ja-sanoilla, mikä on tavallista muissakin tutkimuksissa kuvatuissa johtolauseettomissa referoinneissa. Lisäksi aineistossamme on kaksi autismikirjon henkilön vastausta, joissa ei ole mitään kielellistä elementtiä, joka sitoisi sen meneillään olevaan puhetilanteeseen. Tällaista referointia, jota kutsumme paljaaksi esitykseksi, on aiemmin havaittu ainakin yhdellä autismikirjon lapsella (Engberg-Pedersen \& Christensen 2017, s. 1203-1204, 1209). Jo kauan tätä ennen Kanner (1943, s. 219) raportoi havaintoja, jotka muistuttavat paljasta esitystä. Kannerin raportin kielitieteelliseen antiin on kuitenkin suhtauduttava varauksella siksi, että siinä ei käytetty aineistona nauhoitteita vaan vanhempien muistiin merkitsemiä havaintoja. Siksi emme voi olla varmoja, oliko kyseessä todella paljas esitys vai yhdistyivätkö esitykset esim. kuvaileviin toimintoihin ja johtolauseisiin samassa vuorossa.

Aiempaa tarkkoihin nauhoitteisiin pohjautuvaa keskustelunanalyyttistä tutkimusta autismikirjon lasten kaikupuheesta on suhteellisen runsaasti (esim. Sterponi \& Shankey, 2014; Stribling, Rae, \& Dickerson, 2007), ja olisikin mielenkiintoista tarkastella näissä tutkimuksissa havaittujen ilmiöiden suhdetta paljaaseen esitykseen. Omassa tutkimusase- telmassamme referoinnit eivät ole aiemmin kuultua toistelevaa kaikupuhetta, vaan ne ovat puhtaasti puhujan omaa tuotosta: hänen näkemyksensä siitä, mitä videolla näkyvä henkilö saattaa ajatella. Aineistomme osoittaa myös aikuisten autismikirjon henkilöiden kompetenssia tuottaa esitettyyn kysymykseen vastaus, joskin joissain yksittäistapauksissa muodoltaan harvinainen sellainen. Tunnistamaamme paljasta esitystä sisältävistä vastauksista voi tulkita ilmenevän kaikupuheenkin taustalla olevan deiktisen näkökulman vaihtamisen vaikeuden.

Aineiston pienuuden takia tuloksia tulee kohdella suuntaa-antavina. Myöhemmässä tutkimuksessa voisi olla syytä selvittää, onko joillakin autismikirjon henkilöillä laajemminkin käytössään omaperäisiä referoinnin keinoja, ja pohtia mahdollisia syitä niiden taustalla. Engberg-Pedersen \& Christensen (2017, s. 1198) esittävät, että autismikirjon henkilöt suosivat suoraa esitystä, sillä se on kognitiivisesti helpompaa kuin kahden eri näkökulman yhdistäminen epäsuoraksi esitykseksi. Voidaankin pohtia, olisiko aineistostamme löytyneessä paljaassa esityksessä kyse poikkeavasta tavasta hallita puhetilannetta, jossa ovat samanaikaisesti läsnä sekä puhuja, vastaanottaja että kuvitteellinen kolmas osapuoli, jonka ajatuksista keskustellaan. Tämän tutkimuksen valossa ei voi sanoa, pyrkivätkö paljasta esitystä käyttävät puhujat kognitiiviseen helppouteen (ks. esim. Sperber \& Wilson, 1995) vai onko kyse jostakin muusta kuten esimerkiksi ilmaisun ekonomisuudesta eli pyrkimyksestä jättää ilmaisematta puhetilanteessa ilmiselviä deiktisiä suhteita. On myös korostettava, että autismikirjon henkilöt eivät ole yhtenäinen joukko ja että poikkeavia referointikeinoja esiintyy aineistossamme vain yksittäisillä autismikirjon henkilöillä.

Pidämme tämän tutkimuksen tulosten valossa mahdollisena ja tutkimisen arvoisena, onko referointitilanteen osallistumiskehikko 
(vähintään) kolmine intersubjektiivisine linkkeineen yksi niistä tilanteista, joissa käy ilmi joidenkin aikuisten autismikirjon henkilöiden vaikeus asettaa itseään ja puhekumppaniaan vaihteleviin keskustelurooleihin. Havaintojamme voi tulkita niinkin päin, että ne autismikirjon henkilöt, jotka kielentävät deiktisiä suhteita vähemmän, suhtautuvat puhetilanteen intersubjektiivisiin linkkeihin muita voimakkaammin ja pitävät niitä niin itsestään selvinä, etteivät näe tarvetta niiden ilmaisemiselle. Joka tapauksessa tutkimuksemme jossain määrin tukee aiempia autismikirjon lapsista tehtyjä havaintoja poikkeavasta tavasta ilmaista deiktisiä suhteita. Monilla vaikeammin autistisilla lapsilla poikkeava deiktinen ilmaisu ilmenee kaikupuheena ja epätavallisena pronominien käyttönä. Aineistossamme poikkeavaa deiktistä ilmaisua näyttäisi ilmentävän se, että siinä missä muut puhujat - sekä verrokit että autismikirjon henkilöt - sitovat referointivuorot kielellisesti myös meneillään olevaan puhetilanteeseen huomioiden siten kaksi intersubjektiivista linkkiä ("minä-vastaanottaja" ja "minä-referoitava puhuja"), jotkut yksittäiset autismikirjon aikuiset kielentävät yksinomaan "minä-referoitava puhuja" -linkin vaatiman osuuden.

\section{KIITOKSET}

Kiitämme kaikkia tutkimukseen osallistuneita henkilöitä. Lisäksi kiitos logopedian opiskelija Linda Lönnqvistille ja psykologian opiskelija Laura Mämmelälle aineiston keräämiseen osallistumisesta. Tutkimusta ovat rahoittaneet Suomen Akatemia, Oulun yliopiston Eudaimonia-instituutti, Alma \& K.A.Snellmanin säätiö ja Suomen Aivosäätiö. Kiitos myös Puhe ja kieli -lehden anonyymeille vertaisarvioijille arvokkaasta palautteesta käsikirjoituksen ensimmäiseen versioon.

\section{KÄYTETYT LITTEROINTIMERKIT}

.hhh sisäänhengitys

hhh uloshengitys

- laskeva intonaatio

, tasainen intonaatio

? nouseva intonaatio

(0.6) tauko (pituus sekunteina)

(.) $\quad 0,2 \mathrm{~s}$ tai lyhyempi tauko

(a) äänensävyn muutos

$\boldsymbol{E} \quad$ hymyillen lausuttu jakso

* $\quad$ ympäristöä vaimeampi puhe

sana painotettu sana

$\mathbf{s}(\mathbf{h})$ ana nauraen lausuttu sana

he he nauru

mt maiskaus

sana: äänteen venytys 


\section{LÄHTEET}

Austin, J. L. (1962). How to do things with words. Oxford - New York: Oxford University Press.

Bakhtin, M. M. 1982 [1934]. Discourse in the novel. Teoksessa The Dialogic Imagination: Four Essays, (s. 259-422). Austin: University of Texas Press.

Barnes, J. L., Lombardo, M. V., Wheelwright, S. \& Baron-Cohen, S. (2009). Moral dilemmas film task: A study of spontaneous narratives by individuals with autism spectrum conditions. Autism Research, 2, 148-156.

Baron-Cohen, S. (2009). Autism: The Empathizing-Systemizing (E-S) Theory. The Year in Cognitive Neuroscience, 68-80.

Baron-Cohen, S. (2001). Theory of mind and autism: A review. Special Issue of the International Review of Mental Retardation, 23, 169-184.

Bühler, Karl (2011) [1934]. Theory of Language: The Representational Function of Language. [Sprachtheorie]. Amsterdam: John Benjamins.

Clark, H. \& Gerrig, R.J. (1990). Quotations as demonstrations. Language, 66, 764-805.

Clift, R. \& Holt, E. (2006). Introduction. Teoksessa Reporting talk: Reported speech in interaction, (s. 1-15). Cambridge: Cambridge University Press.

Cummings, L. (2016). Reported speech. A clinical pragmatic perspective. Teoksessa A. Capone, F. Kiefer \& F. Lo Piparo (toim.), Indirect reports and pragmatics. Interdisciplinary studies, (s. 31-54). New York: Springer.

Dornelas, A. \& Pascual, E. (2016). Echolalia as communicative strategy: Fictive interaction in the speech of children with autism. Teoksessa E. Pascual \& S. Sandler (toim.), The Conversation frame: Forms and functions of fictive interaction, (s. 343-361). Amsterdam \& Philadelphia: John Benjamins.

Eiguer, A. (2017). The legacy of Pichon Rivière. Teoksessa R. Losso, L. S. de Setton \& D. E. Scarff (toim.), The linked self in psychoanalysis. The pioneering work of Enrique Pichon Riviére, (s. 197-210). London: Routledge.

Engberg-Pedersen, E. \& Christensen, R. (2017). Mental states and activities in Danish narratives: Children with autism and children with language impairment. Journal of Child Language, 44, 1192-1217.
Freeth, M., Ropar, D., Mitchell, P., Chapman, P. \& Loher, S. (2011). Brief report: How adolescents with ASD process social information in complex scenes. Combining evidence from eye movements and verbal descriptions. Journal of Autism and Developmental Disorders, 41, 364-371.

Frick, M. (2013). Emergent bilingual constructions. Finnish-Estonian codeswitching in interaction. Väitöskirja. Helsingin yliopisto.

Gallese, V. (2011). Intersubjektiivisuus neurotieteen näkökulmasta. Ruumiillinen jäljittely ja sen merkitys intersubjektiivisuudessa. Psykoterapia, 30, 4-17.

Haakana, M. (2005). Sanottua, ajateltua ja melkein sanottua. Puheen ja ajatusten referointi valituskertomuksissa. Teoksessa M. Haakana \& J. Kalliokoski (toim.), Referointi ja moniäänisyys, (s. 114-149). Helsinki: Suomalaisen Kirjallisuuden Seura.

Heritage,J. \& Atkinson,J.M.(1984). Introduction. Teoksessa J. M. Atkinson \& J. Heritage (toim.), Structures of social action. Studies in conversation analysis, (s. 1-15). Cambridge: Cambridge University Press.

Kanner, L. (1943). Autistic disturbances of affective contact. Pathology, 217-250.

Kuiri, K. (1984). Referointi Kainuun ja PohjoisKarjalan murteissa. Helsinki: Suomalaisen Kirjallisuuden Seura.

Kuusikko, S., Pollock-Wurman, R., Jussila, K., Carter, A. S., Mattila, M. L., Ebeling, H., Pauls, D. L. \& Moilanen, I. (2008). Social anxiety in high-functioning children and adolescents with Autism and Asperger syndrome. Journal of Autism and Developmental Disorders, 38, 1697-1709.

Laitinen, L. (1995). Nollapersoona. Virittäjä, 99, 337-358.

Lappalainen, H. (2019). Referointikeinot ja sosiolingvistinen variaatio. Esitelmä Kielitieteen päivillä Joensuussa 18.5.2019.

Laury, R. \& E.-L. Seppänen (2008). Clause combining, interaction, evidentiality, participation structure, and the conjunctionparticle continuum: the Finnish että. Teoksessa R. Laury (toim.), Crosslinguistic studies of clause combiningT he multifunctionality of conjunctions. Typological studies in language, (s. 153-178). Amsterdam: John Benjamins. 
Loukusa, S. (painossa). Autism spectrum disorder. Teoksessa L. Cummings (toim.), Pragmatic language disorders: Complex and underserved populations. Springer.

Mattila, M. L., Kielinen, M., Jussila, K., Linna, S. L., Bloigu, R., Ebeling, H. \& Moilanen, I. (2007). An epidemiological and diagnostic study of Asperger syndrome according to four sets of diagnostic criteria. Journal of the American Academy of Child and Adolescent Psychiatry, 46, 636-646.

Moilanen, I., Mattila, M-L., Loukusa, S. \& Kielinen, M. (2012). Autismikirjon häiriöt lapsilla ja nuorilla. Katsaus. Duodecim, 128, 1453-1462.

Mäkinen, L., Loukusa, S., Leinonen, E., Moilanen, I., Ebeling, H. \& Kunnari, S. (2014). Characteristics of narrative language in autism spectrum disorder: Evidence from the Finnish. Research in Autism Spectrum Disorders, 8, 987996.

Pentikäinen, H. (2007). Autistilapsen polku kommunikatiiviseen kieleen. Pivotal Response Training-menetelmäpuheen ja vuorovaikutuksen rakentajana. Pro gradu -tutkielma. Jyväskylän yliopisto.

Penttilä, A. (1948). Referaatista 1. selosteesta. Virittäjä, 52, 48-69.

Priiki, K. (2014). Antagonistin äänellä. Hänpronominin käyttö valituskertomuksessa. Virittäjä, 118, 194-220.

Routarinne, S. (2005). Keskustelupuheen johtolauseiden kielioppia. Teoksessa M. Haakana \& J. Kalliokoski (toim.), Referointi ja moniäänisyys, (s. 83-113). Helsinki: Suomalaisen Kirjallisuuden Seura.

Sacks, H., Schegloff, E. A. \& Jefferson, G. (1974). A simplest systematics for the organization of turn taking for conversation. Language, 50, 696-735.

Scharff, D. E. (2017). Pichon Riviére and object relations theory. Teoksessa R. Losso, L. S. de Setton \& D. E. Scarff (toim.), The linked self in psychoanalysis. The pioneering work of Enrique Pichon Riviére, (s. 217-232). London: Routledge.

Searle, J. R. (1969). Speech acts. An Essay in the philosophy of language. Cambridge: Cambridge University Press.
Sng, C. Y., Carter, M. \& Stephenson,J.A. (2018).A systematic review of the comparative pragmatic differences in conversational skills of individuals with autism. Autism \& Developmental Language Impairments, 3, 1-24.

Sperber, D. \& Wilson, D. (1995). Relevance: Communication and cognition (2. painos). Blackwell: Oxford, UK.

Sterponi, L. \& Shankey, J. (2014). Rethinking echolalia: Repetition as interactional resource in the communication of a child with autism. Journal of Child Language, 41, 275-304.

Stribling, P., Rae, J. \& Dickerson, P. (2007). Two forms of spoken repetition in a girl with autism. International Journal of Language \& Communication Disorders, 42, 427-444.

Tager-Flusberg, H., Paul, R. \& Lord. C. (2005). Language and communication in autism. Teoksessa F. R. Volkmar, R. Paul, A. Klin \& D. Cohen (toim.), Handbook of autism and pervasive developmental disorders: Diagnosis, development, neurobiology, and behavior, (s. 335-364). Hoboken: John Wiley \& Sons Inc.

Tek, S., Mesite, L., Fein, D. \& Naigles, L. (2014). Longitudinal analyses of expressive language development reveal two distinct language profiles among young children with autism spectrum disorders. Journal of Autism and Developmental Disorders, 44, 75-89.

Varjo, M. (2019): It takes all kinds to make a zero: Employing multiple correspondence analysis to categorize an open personal construction in conversational Finnish. Corpus Linguistics Research, 55-87.

VISK = Hakulinen, A., Vilkuna, M., Korhonen, R., Koivisto, V., Heinonen T. R. ja Alho, I. (2004). Iso suomen kielioppi. Helsinki: Suomalaisen Kirjallisuuden Seura. Verkkoversio. Haettu 4.10.2019 osoitteesta http://scripta. kotus.fi/visk. URN:ISBN:978-952-5446-35-7

Volosinov, V. N. (1973). Marxism and the Philosophy of Language. New York: Seminar Press.

World Health Organization (2018). International classification of diseases for mortality and morbidity statistics ( $11^{\text {th }}$ Revision). Haettu 29.9.2019 osoitteesta https://icd.who.int/ browse11/1-m/en. 


\section{HOW DO PEOPLE ON THE AUTISM SPECTRUM DISORDER AND CONTROL GROUP MEMBERS ASSERT AND DEMONSTRATE THOUGHTS OF ANOTHER PERSON?}

Maria Frick, Research Unit of Languages and Literature, University of Oulu

Soile Loukusa, Research Unit of Logopedics, University of Oulu

Katja Dindar, Research Unit of Logopedics, University of Oulu

Leena Mäkinen, Research Unit of Logopedics, University of Oulu

Marja-Leena Mattila, PEDEGO Research Unit, Faculty of Medicine, University of Oulu and

Clinic of Child Psychiatry, Oulu University Hospital

Hanna Ebeling, PEDEGO Research Unit, Faculty of Medicine, University of Oulu and

Clinic of Child Psychiatry, Oulu University Hospital

Tuula Hurtig, Research Unit of Clinical Neuroscience, PEDEGO Research Unit,

University of Oulu and Clinic of Child Psychiatry, Oulu University Hospital

This paper examines participants' responses to questions regarding the thoughts of another person. The data is drawn from semi-structured interviews with 56 young adults, 26 of whom have been diagnosed with autism spectrum disorder. The interviews are in Finnish. The focus of this study is on linguistic means used by the participants in a task in which they are asked to watch a video clip and then tell what one of the characters is thinking. A common type of response to the latter question is an assertion, such as noo (.) se oli selvästi kiinnostunu siitä (2.0) kurssista ja (.) siitä mitä siellä tehdään ja 'well, she was clearly interested in the course and what it's all about and', which names the thought (e.g., kiinnostunu interested'). The responses also include demonstrations, such as kuulostaapa tosi hauskalta kurssilta haluanpa itsekin mukaan sinne That sounds like a fun course. I think I'd like to join.' The study shows that individuals on the autism spectrum and control group members use similar linguistic means in their reported speech utterances.

Most demonstrations in the data are combined with an assertion or other markers that show a deictic shift between the reported speech situation and the situation here-and-now. Two individuals on the autism spectrum, however, use a rare type of 'bare demonstration' which is not linguistically tied to the situation here-and-now. We pose a hypothesis that this may reflect some difficulty of individuals on the autism spectrum in processing the complex participation framework in a reported thought situation. In this part, 'bare demonstrations' resemble repetitive speech of children on the autism spectrum, which also reflects difficulty in intersubjective processing and interactional deictics. However, bare demonstrations are not reproductions of something the speaker has heard but, instead, a creation of the speaker's own imagination.

Keywords: autism spectrum, direct speech, intersubjectivity, reported speech 